\title{
INFECTION RISK ANALYSIS OF 101 SILVER-COATED ENDOPROSTHESES
}

\author{
ANALIZA TVEGANJA ZA OKUŽBO PRI 101 POSREBRENIH \\ ENDOPROTEZAH
}

\author{
Blaž Mavčičč ${ }^{1,2 *}$, David Martinčič ${ }^{1}$, Marko Špiler ${ }^{1}$, Vane Antolič ${ }^{1,2}$ \\ ${ }^{1}$ University Medical Centre Ljubljana, Department of Orthopedic Surgery, Zaloška cesta 9, 1000 Ljubljana, Slovenia \\ ${ }^{2}$ University of Ljubljana, Faculty of Medicine, Zaloška cesta 9, 1000 Ljubljana, Slovenia
}

Prejem rokopisa - received: 2019-05-06; sprejem za objavo - accepted for publication: 2019-05-23

doi: $10.17222 / \mathrm{mit} .2019 .094$

\begin{abstract}
Our aim was to analyse the implant survival and infection rates of 101 consecutive silver-coated MUTARS ${ }^{2}$ (= Modular Universal Tumour And Revision System) endoprostheses implanted at an independent orthopaedic tertiary hospital between April 1, 2011 and December 31, 2018 and to compare them with previous outcomes of the MUTARS® developmental hospitals. In addition, we tested the hypothesis that the infection-free survival rates of silver-coated implants depend on the patient's age, gender, pre-operative diagnoses and anatomical localization of the reconstruction. The cohort included 47 sarcoma resections, 29 revision arthroplasties, 20 metastatic resections, 3 benign bone tumours and 2 primary arthroplasties. Endoprosthesis was located in the distal femur (38 patients), proximal femur (29 patients), proximal humerus (12 patients), proximal tibia (10 patients), pelvis (6 patients), total femur (5 patients) and distal humerus (1 patient). The mean age at implantation was 49 (range 11-86) years and the mean follow-up 3.2 (range 0.1-7.7) years. Twenty-four patients required at least one subsequent revision operation and 15 endoprostheses had to be partially/totally removed. Patients' age was an independent risk factor for postoperative infection regardless of other confounding factors (hazard ratio 1.05 for each year; $p=0.02$ ). With the overall postoperative infection rate $12 \%$ (4\% reinfection $+8 \%$ newly acquired) and cumulative partial/total implant removal rate $25 \%$ after 5 years, complications were comparable to the previous series of the MUTARS® developmental hospitals with high variability between preoperative diagnoses and anatomical localizations. Silver-coated implants show a consistent trend of preventing infections in high-risk body regions and enabling more successful treatment should infection occur, but 10-15 years of clinical follow-up is required for further assessment.

Keywords: bone defect, modular endoprostheses, silver coating
\end{abstract}

Namen raziskave je bil analizirati preživetje vsadkov in pogostnost okužb v kohorti 101 zaporednih modularnih endoprotez MUTARS® (= Modularni univerzalni tumorski in revizijski sistem) s posrebreno površino, ki so bile vstavljene v neodvisni terciarni ortopedski kliniki med 1. aprilom 2011 in 31. decembrom 2018, ter jih primerjati s predhodnimi rezultati razvojnih bolnišnic vsadka MUTARS®. Poleg tega smo preverjali hipotezo, ali je preživetje posrebrenih vsadkov brez okužbe odvisno od starosti pacienta, spola, predoperativne diagnoze in anatomskega področja rekonstrukcije. Skupina je obsegala 47 resekcij sarkoma, 29 revizijskih artroplastik, 20 resekcij zasevkov, 3 benigne kostne tumorje in 2 primarni artroplastiki. Endoproteze so bile vstavljene $\mathrm{v}$ distalno stegnenico (38 pacientov), proksimalno stegnenico ( 29 pacientov), proksimalno nadlahtnico (12 pacientov), proksimalno golenico (10 pacientov), medenico (6 pacientov), celotno stegnenico (5 pacientov) in distalno nadlahtnico (1 pacient). Povprečna starost ob vstavitvi endoproteze je znašala 49 (razpon 11-86) let, klinično spremljanje pa 3,2 (razpon $0,1-7,7)$ let. Stiriindvajset pacientov je potrebovalo vsaj eno naknadno revizijsko operacijo in 15 endoprotez je bilo treba delno/popolnoma odstraniti. Starost pacienta je bila neodvisen dejavnik tveganja za pooperativno okužbo ne glede na ostale pridružene spremenljivke (razmerje tveganja 1,05 za vsako leto starosti; $\mathrm{p}=0,02)$. S skupnim deležem okužb $12 \%(4 \%$ ponovna okužba $+8 \%$ novo pridobljena) in kumulativnim deležem delnih/popolnih odstranitev endoprotez pri $25 \%$ pacientov $\mathrm{V}$ prvih 5 letih spremljanja je bila pogostnost zapletov primerljiva s predhodno objavljenimi raziskavami razvojnih bolnišnic MUTARS®. Posrebreni vsadki v vseh raziskavah nakazujejo trend preprečevaja okužb in omogočajo bolj uspešno zdravljenje, če do okužbe pride. Nadaljnje spremljanje v obdobju 10-15 let bo pokazalo, ali takšni srednjeročni rezultati napovedujejo tudi dobre dolgoročne izide.

Ključne besede: kostni defekt, modularne endoproteze, posrebrena površina

\section{INTRODUCTION}

In the past two decades the trend of bone defect reconstructions in limbs has shifted to the implantation of massive, large modular endoprostheses ${ }^{1,2}$ with an inherent risk of periendoprosthetic infection, most likely by styaphylococci. ${ }^{3,4}$ Endoprosthetic infections have been reported in up to $19 \%$ of cases in proximal femur replacements, ${ }^{1,5}$ up to $11 \%$ of cases in distal femur replacements, ${ }^{1,2}$ up to $23 \%$ of cases in proximal tibia

*Corresponding author e-mail:

blaz.mavcic@kclj.si replacements and up to $43 \%$ of previously infected endoprostheses. ${ }^{4}$ Manufacturers have been trying to reduce endoprosthetic infection rates with antimicrobial implant surfaces like antibiotic-based, antiseptic, photoactive-based or silver coatings. ${ }^{6-8}$ Antibiotic coatings have limited duration of drug elution and the risk of resistance, ${ }^{9}$ while effective antiseptic coatings (chlorhexidine, chloroxylenol) also exhibit toxicity. ${ }^{2,10}$ The nanostructured topography of the implants has also been tested in vitro for anti-bacterial properties, ${ }^{11-14}$ whereby mesenchymal and embryonic stem cells were unable to grow on surfaces with particular $\mathrm{TiO}_{2}$ nanotube dimen- 
sions ${ }^{14}$. Metallic coating with silver has a low level of human toxicity and longer-lasting antimicrobial silver ion activity since the ions are only released into solution from the implant surface at negative $\mathrm{pH}$ values. ${ }^{15,16}$ The antimicrobial efficacy of silver-coated endoprostheses has not yet been confirmed in randomized controlled studies, but several retrospective studies analysed different implants, ${ }^{17,18}$ among them the widely used MUTARS $®$ system (= Modular Universal Tumour And Revision System, Implantcast $\mathrm{GmbH}$ ). ${ }^{1-4,6,19-24}$ These studies were either conducted by the main developmental hospital of this manufacturer (University Hospital Münster, Münster, Germany) $)^{1,3,6,15,21,24}$ or in smaller centres with patient series of $25-40$ patients and $<2$ years

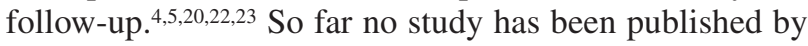
an independent institution with the entire cohort of a hundred silver-coated MUTARS $®$ implants and over 3 years of mean follow-up.

The aim of the presented study was to analyse the infection rates and implant survival rates of the entire cohort of 101 consecutive silver-coated MUTARS $®$ modular endoprostheses implanted at an independent orthopaedic tertiary hospital with up to 7.7 years of follow-up and to compare them with previously published outcomes of the developmental hospital for this endoprosthetic system. In addition, we tested the hypothesis that the infection-free survival rates of silver-coated implants depend on the patient's age, gender, pre-operative diagnoses and anatomical localization of the reconstructed bone defect.

\section{MATERIALS AND METHODS}

A retrospective observational study of prospectively collected data included an entire cohort of patients with silver-coated MUTARS $®$ endoprostheses implanted at a single orthopaedic oncological tertiary hospital between April 1, 2011 and December 31, 2018. Medical documentation was collected from the archives in order to obtain the data on: pre-operative diagnosis, patient's age and gender at the time of surgery, localization of the bone defect to be reconstructed, implanted MUTARS ${ }^{\circledR}$ endoprosthesis type, all recorded complications during implantation and in the course of the follow-up period, possible revision operations, the need for partial/total implant removal and infection-free implant survival until December 31, 2018 or possible death before the end of the observation period. None of the patients was excluded from the study or lost from the follow-up.

Statistical data analysis was performed with Office Excel 2016 (Microsoft Corp, Redmond, WA) and IBM SPSS Statistics 23.0 for Windows (IBM Corp, Armonk, NY). Cumulative incidences of partial/total implant removal for any reason were assessed after 1,2 and 5 years of follow-up. The survival of silver-coated MUTARS ${ }^{\circledR}$ implants until infection, until the first revision or until partial/total implant removal was assessed with the Cox regression models and covariables of age, gender, preoperative diagnoses (sarcoma resection / metastasis resection / revision of previously uninfected arthroplasty / revision of previous artificial joint infection) and anatomical localization (proximal and total femur / distal femur / proximal tibia / humerus / pelvis). Statistical significance was set at $P \leq 0.05$.

\section{RESULTS}

The study cohort included 101 consecutive silvercoated MUTARS® endoprostheses with 47 cases of primary sarcoma resection, 29 revision arthroplasties after previous reconstruction (18 previous joint arthroplasties and 11 previous sarcoma resections), 20 metastatic resections, 3 aggressive benign bone tumours and 2 complex primary total knee arthroplasties. The endoprosthesis was located in the distal femur in 38 patients, proximal femur in 29 patients, proximal humerus in 12 patients, proximal tibia in 10 patients, pelvis in 6 patients, total femur in 5 patients and distal humerus in 1 patient. The mean age at implantation was $49 \pm 20$ years (range 11-86 years) and the mean follow-up of patients was $3.2 \pm 2.2$ years (range $0.1-7.7$ years). We recorded 4 local tumour relapses and 20 patients died due to oncological disease.

Twenty-four patients (24\%) required at least one surgical revision of the silver-coated implant at a median 1.1 year after the initial implantation and 15 endoprostheses $(15 \%)$ had to be at least partially replaced or entirely removed. Nine patients in the cohort had previously been diagnosed/treated for artificial joint infection before the silver-coated MUTARS ${ }^{\circledR}$ endoprosthesis was implanted and therefrom 4 infections subsequently recurred; with an additional 8 cases of newly acquired deep infections after the silver-coated MUTARS ${ }^{\circledR}$ endoprosthesis implantation the total deep infection rate was therefore 12 cases (12\%). In the subgroup of newly acquired infections, 1 case was in the proximal femur (3\% location-specific infection rate), 3 in the distal femur (8\% location-specific infection rate), 2 in the proximal tibia (20\% location-specific infection rate) and 2 in pelvis (33\% location-specific infection rate). Altogether, 6 silver-coated MUTARS $®$ implants had to be explanted eventually due to infection and 6 were retained with cured infection. Cumulative incidences of at least partial replacement or entire implant removal for any reason were $4 \%$ after 1 year $(1 \%$ mechanical reasons / $3 \%$ infection), $15 \%$ after 2 years (9\% mechanical reasons / $5 \%$ infection / $1 \%$ tumour relapse) and $25 \%$ after 5 or more years of follow-up (13\% mechanical reasons / $8 \%$ infection / $3 \%$ tumour relapse).

When the infection-free survival of silver-coated MUTARS ${ }^{\circledR}$ implants was assessed with the Cox regression models and covariables of age, gender, preoperative diagnoses and anatomical localization (Table 1), it 


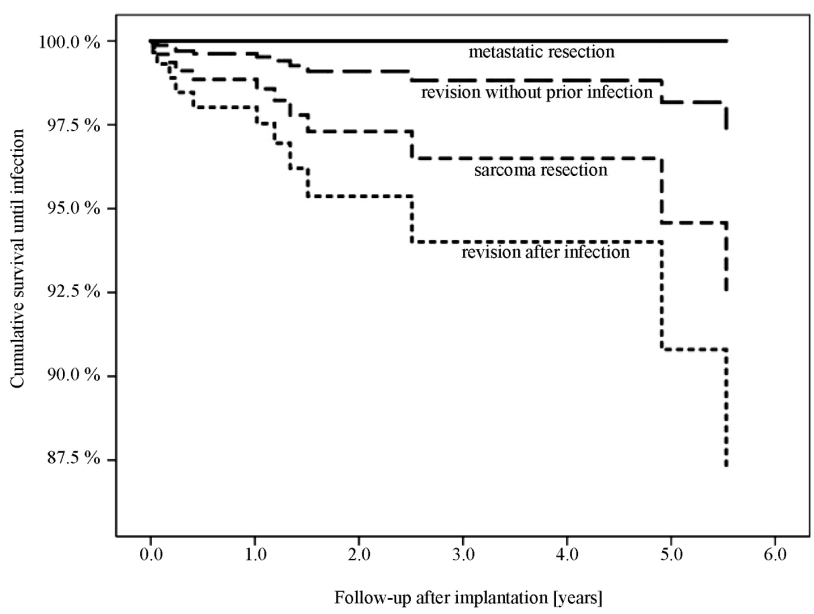

Figure 1: Cox regression model of infection-free survival in the cohort of 101 silver-coated MUTARS $®$ endoprostheses, stratified according to the pre-operative diagnosis. Differences between strata were not statistically significant.

turned out that a higher age at implantation was an independent risk factor for implant infection, regardless of all the other confounding factors (hazard ratio 1.05 for each year; $p=0.02)$. There was also a trend of shorter infection-free survival rates in patients with previously diagnosed/treated infection (Figure 1) or pelvic resection (Figure 2), but the trend was not statistically significant. On the other hand, age, gender, preoperative diagnoses and anatomical localization had no statistically significant impact on Cox regression implant survival until the first revision or partial/total implant removal.

\section{DISCUSSION}

The limitations of the presented study include retrospective design, a high percentage of deceased patients for oncological reasons and consequently a high number of censored observations. Furthermore, the results in

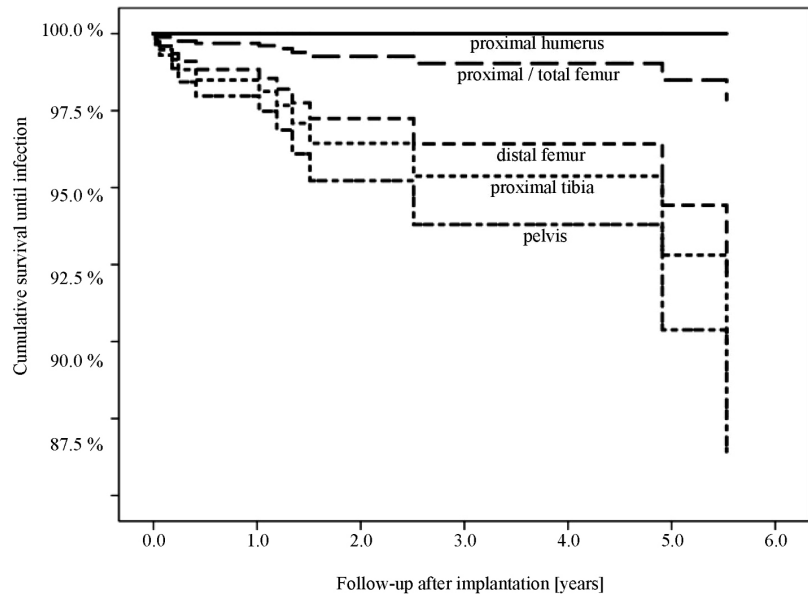

Figure 2: Cox regression model of infection-free survival in the cohort of 101 silver-coated MUTARS ${ }^{\circ}$ endoprostheses, stratified according to the anatomical localization. Differences between strata were not statistically significant.

revision arthroplasty patients are difficult to analyse within or between different centres due to different diagnostic methods of infection (e.g., sonication), perioperative antibiotic regiments, number of previous surgical procedures and pre-existing infections. All these limitations were also present in all other recent studies of this topic ${ }^{1-6,19-24}$ where the infection-rate variability of silver-coated implants was larger between different patient populations (primary resection, metastases, revision, previous infection) and anatomical localizations than between different implant types (silver-coated vs. non-coated). ${ }^{2}$ However, within each selected patient population and anatomical localization, silver-coated implants have consistently shown lower infection rates in comparison to other implants ${ }^{18,25-26}$ and our results corroborate these findings in the setting of an independent institution with longer follow-up from previous smaller patient series. ${ }^{4,5,20,22,23}$ The overall $12 \%$ infection rate of the presented study is almost identical to the previously

Table 1: Cox regression model of infection-free survival in the entire cohort of 101 silver-coated MUTARS $®$ implants with covariables of age, gender, preoperative diagnose and anatomical localization (overall score Chi-square $24.2 ; p<0.01$ ). Statistically significant P-values $\leq 0.05$ are marked with an asterisk (*).

\begin{tabular}{|c|c|c|c|c|c|c|}
\hline & $\mathrm{B}$ & SE & $\operatorname{Exp}(B)$ & \multicolumn{2}{|c|}{$95 \% \mathrm{CI}$} & $\mathrm{P}$-value \\
\hline AGE [years] & 0.05 & 0.02 & 1.05 & 1.01 & 1.10 & $0.02 *$ \\
\hline GENDER [female] & -0.24 & 0.63 & 0.79 & 0.23 & 2.70 & 0.70 \\
\hline $\begin{array}{l}\text { PREOPERATIVE DIAGNOSE } \\
\text { [ref] sarcoma resection } \\
\text { metastasis resection } \\
\text { revision without prior infection } \\
\text { revision after infection }\end{array}$ & $\begin{array}{c}-1.65 \\
-0.55 \\
-12.89\end{array}$ & $\begin{array}{c}0.91 \\
0.74 \\
306.24\end{array}$ & $\begin{array}{l}0.19 \\
0.58 \\
0.00\end{array}$ & $\begin{array}{l}0.03 \\
0.14 \\
0.00 \\
\end{array}$ & $\begin{array}{l}1.13 \\
2.44 \\
1.19 \\
\end{array}$ & $\begin{array}{l}0.34 \\
0.07 \\
0.46 \\
0.97 \\
\end{array}$ \\
\hline $\begin{array}{l}\text { LOCALIZATION } \\
\text { [ref] prox./total femur } \\
\text { distal femur } \\
\text { proximal tibia } \\
\text { pelvis } \\
\text { humerus }\end{array}$ & $\begin{array}{c}-1.87 \\
-0.30 \\
-12.00 \\
-0.55\end{array}$ & $\begin{array}{c}1.30 \\
0.95 \\
304.23 \\
0.99\end{array}$ & $\begin{array}{l}0.15 \\
0.74 \\
0.00 \\
0.58\end{array}$ & $\begin{array}{l}0.01 \\
0.12 \\
0.00 \\
0.08\end{array}$ & $\begin{array}{l}1.95 \\
4.76 \\
5.63 \\
3.99\end{array}$ & $\begin{array}{l}0.65 \\
0.15 \\
0.76 \\
0.97 \\
0.58\end{array}$ \\
\hline
\end{tabular}

B-regression line coefficient, SE-standard error, $\operatorname{Exp}(\mathrm{B})$-hazard ratio, CI-confidence interval, [ref]-reference category 


\section{B. MAVČIČ et al.: INFECTION RISK ANALYSIS OF 101 SILVER-COATED ENDOPROSTHESES}

published series of mixed primary resections with revision arthroplasty where Glehr et al. ${ }^{27}$ reported an infection rate of $12.5 \%$ among 32 patients who had been treated with MUTARS® silver-coated endoprostheses and Wafa et al. ${ }^{18}$ reported an overall postoperative infection rate of $11.8 \%$ in the silver-coated group of 85 Agluna-Stanmore Implants. Likewise, Schmolders et al. ${ }^{4}$ had to perform revision operations due to infection in $10 \%$ of their implanted silver-coated MUTARS ${ }^{\circledR}$ endoprostheses after a median follow-up of 24 months for primary or metastatic oncological patients. On the other hand, infection rates for silver-coated implants in primary tumour resections (i.e., unrevised and uninfected previously) of selected anatomical localizations (proximal and distal femur) were consistently lower: 3-8 \% in the presented study and 4-7\% in the studies of the main MUTARS $®$ developmental institution. ${ }^{6}$

The presented study is the first one in the field of silver-coated implants to demonstrate patients' age has as an independent risk factor of infection. This finding is not surprising as age-related higher complication rates have already been identified in the treatment of uncoated endoprosthetic infections, ${ }^{28}$ the osteosynthesis of long bones, ${ }^{29}$ and spinal fusion. ${ }^{30}$ Although the patients' age itself is a non-modifiable factor, additional precautionary measures could be applied in elderly patients to reduce the implant infection risk, e.g., different perioperative antibiotic regimens, the use of local muscular flaps to ensure sufficient soft-tissue coverage or earlier aggressive drainage of haemathomas. ${ }^{31}$ Not in the least, our findings indicate that age should be one of the factors when deciding upon the optimal radicality of the bone tumour resection or the complexity of the bone defect reconstruction in elderly patients.

\section{CONCLUSIONS}

This is the first study of a large MUTARS® silvercoated endoprosthesis cohort performed by an independent institution with up to 7.7 years of follow-up. With the cumulative partial/total implant removal rate of $25 \%$ after 5 years and postoperative infection in $12 \%$ of cohort patients, the complication rates were comparable to the previously published series of developmental hospitals with a high variability in results between different preoperative diagnoses and anatomical localizations. Patients' age at implantation was identified as an independent risk factor for subsequent infection, regardless of all the other confounding factors.

\section{Acknowledgment}

This work was carried out at the Department of Orthopaedic Surgery, University Medical Centre Ljubljana, with no extra funding.

\section{Ethics statement}

The study protocol was reviewed and approved by the National Medical Ethics Committee of the Republic of Slovenia on September 19, 2017, case no.\# 120-486/2017. All procedures performed in studies involving human participants were in accordance with the institutional/national ethical standards and with the Helsinki declaration and its later amendments.

\section{Conflict of interest}

The authors declare they have no conflict of interest.

\section{REFERENCES}

${ }^{1}$ G. Gosheger, C. Gebert, H. Ahrens, A. Streitbuerger, W. Winkelmann, J. Hardes, Endoprosthetic reconstruction in 250 patients with sarcoma, Clin Orthop Relat Res, 450 (2006), 164-167, doi:10.1097/01.blo.0000223978.36831.39

${ }^{2}$ T. Schmidt-Braekling, A. Streitbuerger, G. Gosheger, F. Boettner, M. Nottrott, H. Ahrens, R. Dieckmann, W. Guder, D. Andreou, G. Hauschild, B. Moellenbeck, W. Waldstein, J. Hardes, Silver-coated megaprostheses: review of the literature, Eur J Orthop Surg Traumatol, 27, 4 (2017), 483-489, doi:10.1007/s00590-017-1933-9

${ }^{3}$ J. Hardes, C. Gebert, A. Schwappach, H. Ahrens, A. Streitburger, W. Winkelmann, G. Gosheger, Characteristics and outcome of infections associated with tumor endoprostheses, Arch Orthop Trauma Surg, 126, 5 (2006), 289-296, doi:10.1007/s00402-005-0009-1

${ }^{4}$ J. Schmolders, S. Koob, P. Schepers, P. H. Pennekamp, S. Gravius, D. C. Wirtz, R. Placzek, A. C. Straus, Lower limb reconstruction in tumor patients using modular silver-coated megaprostheses with regard to perimegaprosthetic joint infection: a case series, including 100 patients and review of the literature, Arch Orthop Trauma Surg, 137, 2 (2017), 149-153, doi:10.1007/s00402-016-2584-8

${ }^{5}$ P. T. Funovics, C. Hipfl, J. G. Hofstaetter, S. Puchner, R. I. Kotz, M. Dominkus, Management of septic complications following modular endoprosthetic reconstruction of the prox. femur, Int Orthop, 35, 10 (2011), 1437-1444, doi:10.1007/s00264-010-1054-0

${ }^{6}$ J. Hardes J, C. von Eiff, A. Streitbuerger, M. Balke, T. Budny, M. P. Henrichs, G. Hauschild, H. Ahrens, Reduction of periprosthetic infection with silver-coated megaprostheses in patients with bone sarcoma, J Surg Oncol, 101, 5 (2010), 389-395, doi:10.1002/ jso. 21498

${ }^{7}$ S. Veerachamy, T. Yarlagadda, G. Manivasagam, P. K. Yarlagadda, Bacterial adherence and biofilm formation on medical implants: a review, Proc Inst Mech Eng, Part H, J Eng Med 228, 10 (2014), 1083-1099, doi:10.1177/0954411914556137

${ }^{8}$ A.E. Eltorai, J. Haglin, S. Perera, B. A. Brea, R. Ruttiman, D. R. Garcia, C. T. Born, A. H. Daniels, Antimicrobial technology in orthopedic and spinal implants, World J Orthop, 7, 6 (2016), 361-369, doi:10.5312/wjo.v7.i6.361

${ }^{9}$ C. R. Arciola, D. Campoccia, Y. H. An, L. Baldassarri, V. Pirini, M. E. Donati, F. Pegreffi, L. Montanaro, Prevalence and antibiotic resistance of 15 minor staphylococcal species colonizing orthopedic implants, Int J Artif Organs, 29, 4 (2006), 395-401

${ }^{10}$ K. M. Ho, E. Litton, Use of chlorhexidine-impregnated dressing to prevent vascular and epidural catheter colonization and infection: a meta-analysis, J Antimicrob Chemother 58, 2 (2006) 281-287, Erratum J Antimicrob Chemother, 65, 4 (2010), 815, doi:10.1093/ $\mathrm{jac} / \mathrm{dk} 1234$

${ }^{11}$ Y. Zheng, J. Li, X. Liu, J. Sun, Antimicrobial and osteogenic effect of Ag-implanted titanium with a nanostructured surface, Int $\mathbf{J}$ Nanomedicine, 7 (2012), 875-884, doi:10.2147/IJN.S28450 


\section{B. MAVČIČ et al.: INFECTION RISK ANALYSIS OF 101 SILVER-COATED ENDOPROSTHESES}

${ }^{12}$ N. G. Durmus, E. N. Taylor, F. Inci, K. M. Kummer, K. M. Tarquinio, T. J. Webster, Fructose-enhanced reduction of bacterial growth on nanorough surfaces, Int J Nanomedicine, 7 (2012), 537-545, doi:10.2147/IJN.S27957

${ }^{13}$ K. Narendrakumar, M. Kulkarni, O. Addison, A. Mazare, I. Junkar, P. Schmuki, R. Sammons, A. Iglič, Adherence of oral streptococci to nanostructured titanium surfaces, Dent Mater, 31, 12 (2015), 1460-1468, doi:10.1016/j.dental.2015.09.011

${ }^{14}$ M. Kulkarni, I. Junkar, P. Humpolíček, Z. Capáková, K. A. Radaszkiewicz, N. Mikušová, J. Pacherník, M. Lehocký, A. Iglič, M. Hanáčková, M. Mozetič, Interaction of nanostructured $\mathrm{TiO}_{2}$ biointerfaces with stem cells and biofilm-forming bacteria, Mater Sci Eng C Mater Biol Appl, 77 (2017), 500-507, doi:10.1016/ j.msec.2017.03.174

${ }^{15}$ G. Gosheger, J. Hardes, H. Ahrens, A. Streitburger, H. Buerger, M. Erren, A. Gunsel, F. H. Kemper, W. Winkelmann, C. von Eiff, Silver-coated megaendoprostheses in a rabbit model - an analysis of the infection rate and toxicological side effects, Biomaterials, 25, 24 (2004), 5547-5556, doi:10.1016/j.biomaterials.2004.01.008

${ }^{16} \mathrm{~J}$. W. Alexander, History of the medical use of silver, Surg Infect, 10, 3 (2009), 289-292, doi:10.1089/sur.2008.9941

${ }^{17}$ F. Donati, G. Di Giacomo, S. D’Adamio, A. Ziranu, S. Careri, M. Rosa, G. Maccauro, Silver-coated hip megaprosthesis in oncological limb savage surgery, Biomed Res Int, 2016 (2016), 9079041, doi:10.1155/2016/9079041

${ }^{18}$ H. Wafa, R. J. Grimer, K. Reddy, L. Jeys, A. Abudu, S. R. Carter, R. M. Tillman, Retrospective evaluation of the incidence of early periprosthetic infection with silver-treated endoprostheses in high-risk patients: case-control study, Bone Joint J, 97-B, 2 (2015), 252-257, doi:10.1302/0301-620X.97B2.34554

${ }^{19}$ A. Ezquerra, A. Peguero Bona, Use of silver coating in tumoral prosthetic surgery: influence on infection rate, Aguilar Rev Fac Cien Med Univ Nac Cordoba 74, 3 (2017), 239-242, doi:10.31053/ 1853.0605.v74.n3.14892

${ }^{20}$ D. Zajonz, U. Birke, M. Ghanem, T. Prietzel, C. Josten, A. Roth, J. K. M. Fakler, Silver-coated modular megaendoprostheses in salvage revision arthroplasty after periimplant infection with extensive bone loss - a pilot study of 34 patients, BMC Musculoskelet Disord 18, 1 (2017), 383, doi:10.1186/s12891-017-1742-7

${ }^{21}$ J. Hardes, M. P. Henrichs, G. Hauschild, M. Nottrott, W. Guder, A. Streitbuerger, Silver-coated megaprosthesis of the proximal tibia in patients with sarcoma, J Arthroplasty, 32, 7 (2017), 2208-2213, doi:10.1016/j.arth.2017.02.054

${ }^{22}$ J. Schmolders, S. Koob, P. Schepers, M. Kehrer, S. P. Frey, D. C. Wirtz, P. H. Pennekamp, A. C. Strauss, Silver-coated endoprosthetic replacement of the proximal humerus in case of tumour-is there an increased risk of periprosthetic infection by using a trevira tube? Int Orthop, 41, 2 (2017), 423-428, doi:10.1007/s00264-016-3329-6

${ }^{23}$ J. Schmolders, S. Koob, P. Schepers, S. Gravius, D. C. Wirtz, C. Burger, P. H. Pennekamp, A. C. Strauss, The role of a modular universal tumour and revision system (MUTARS®) in lower limb endoprosthetic revision surgery - outcome analysis of 25 patients, $\mathrm{Z}$ Orthop Unfall, 155, 1 (2017), 61-66, doi:10.1055/s-0042-114704

${ }^{24}$ A. Streitbuerger, M. P. Henrichs, G. Hauschild, M. Nottrott, W. Guder, J. Hardes, Silver-coated megaprostheses in the proximal femur in patients with sarcoma, Eur J Orthop Surg Traumatol, 29 (2019), doi:10.1007/s00590-018-2270-3

${ }^{25}$ G. Scoccianti, F. Frenos, G. Beltrami, D. A. Campanacci, R. Capanna, Levels of silver ions in body fluids and clinical results in silver-coated megaprostheses after tumour, trauma or failed arthroplasty, Injury, 47, suppl 4 (2016), S11-S16, doi:10.1016/ j.injury.2016.07.042

${ }^{26}$ F. Donati, G. Di Giacomo, S. D’Adamio S, A. Ziranu, S. Careri, M. A. Rosa, G. Maccauro, Silver-coated hip megaprosthesis in oncological limb savage [sic] surgery, Biomed Res Int, 6 (2016), 9079041, doi:10.1155/2016/9079041

${ }^{27}$ M. Glehr, A. Leithner, J. Friesenbichler, W. Goessler, A. Avian, D. Andreou, W. Maurer-Ertl, R. Windhager, P. U. Tunn, Argyria following the use of silver-coated megaprostheses: no association between the development of local argyria and elevated silver levels, Bone Joint J, 95, 7 (2013), 988-992, doi:10.1302/0301-620X. 95B7.31124

${ }^{28}$ M. Wouthuyzen-Bakker, M. Sebillotte, J. Lomas and ESCMID Study Group for Implant-Associated Infections, Clinical outcome and risk factors for failure in late acute prosthetic joint infections treated with debridement and implant retention, J Infect, (2018), S01634453(18)30241-X, doi:10.1016/j.jinf.2018.07.014

${ }^{29}$ D. P. J. Smeeing, J. P. Briet, C. S. van Kessel, M. M. Segers, E. J. Verleisdonk, L. P. H. Leenen, R. M. Houwert, F. Hietbrink, Factors associated with wound- and implant-related complications after surgical treatment of ankle fractures, J Foot Ankle Surg, 57, 5 (2018), 942-947, doi:10.1053/j.jfas.2018.03.050

${ }^{30}$ A. C. Rienmüller, S. M. Krieg, F. A. Schmidt, E. L. Meyer, B. Meyer, Reoperation rates and risk factors for revision 4 years after dynamic stabilization of the lumbar spine, Spine J, 19, 1 (2019), 113-120, doi:10.1016/j.spinee.2018.05.025

${ }^{31}$ M. M. Malawer, J. C. Wittig, J. Bickels, S. W. Wiesel, Operative Techniques in Orthopaedic Surgical Oncology, $2^{\text {nd }}$ ed., Wolters Kluwer, Philadelphia (2016), 45-47 